\title{
Erratum Volume 17 Issue 3
}

\section{May-June 2009}

\section{Page 409}

For:

3. Trzesniak P. Divulgação Científica. In: I Simpósio Sulbrasileiro de Editoração Cientifica. Umuarama (PR); 2002.

Read:

3. Greene LJ. O trabalho científico: enfoque do editor. In: Trzesniak P (Ed.). X Curso de Editoração Científica notas de aula compiladas. Petrópolis: Associação Brasileira de Editores Científicos; 2001. p. 43-5. 